\title{
Traditions of the Russian Popular Science Journalism in the Socio-Cultural Context
}

\author{
Yuliya B. Balashova, PhD (Doctor of Science), \\ Professor at Saint Petersburg State University, Russia
}

Doi: 10.19044/esj.2018.c5p12～URL:http://dx.doi.org/10.19044/esj.2018.c5p12

\begin{abstract}
The article is devoted to the historically established dominants of the science mediatization in Russia. As the main channel of the popular knowledge, the popular science press was segregated. The historical experience of the popular science journalism development shows it's steadily focused on the commonwealth of the sciences, and audience worldview formation.

From the modern terminology point of view, the very model of the Russian popular science press should be determined as a trans-media, or hybrid media, with an organic combination of the educational, enlightenment and entertainment functions.
\end{abstract}

Keywords: Science communication, popular science journalism, Russian science and culture

\section{Introduction}

At present, the issues of the science mediatization seem to be among the most urgent. Science is capable of successfully developing exclusively in a global context. The globalization of scientific knowledge contributes to awareness not only common threats, but also the desire to bring science closer to the interests of society. But along with the global trend "science with and for society" a stable negative phenomenon, such as rejection of science, or resistance to science, clearly manifested itself.

Knowledge at all times is a value. The problem of science popularization exists as much as the science itself. Historically, considerable experience of the science mediatization has been accumulated. Russia is such a country with a rich history. Traditionally science held a high position in Russian society, has been included in the public sphere. But, at the same time, it's important to take into account the differences between Russian and the Western traditions and mindset. 
Among universal traditional forms of the science mediatization are: scientific societies, museums, libraries, educational films and lectures, the sphere of non-formal education and enlightenment. Media are the decisive factors in the spread of science enlightenment. Science and popular press is an intellectual resource, which should satisfy the need for knowledge about the world. On this way the popular science magazine is crucial. It's appropriate to recall that the magazine as a type of edition originated precisely as a popular science magazine (such as "Journal des Scavans", which began to publish in 1665 in Paris). This communicative channel is extremely significant for the performance of science, if the agenda is the dissemination of knowledge about reality, the struggle against pseudoscience. Popular science magazine in Russia should focus on the integration of sciences, synthesis of science and human knowledge. This is the key difference from its Western analogues, showing greater specialization.

To date, there are certain signs of the Russian popular science journalism revival. It is obvious that the popular science press should rely not only on Western analogues, but also the rich domestic tradition of science popularization.

However, there are no fundamental studies on the history of science mediatization, and not only in the Russian, but also in the English-speaking scientific community.

\section{I.}

\section{Research question}

What are the national features of the science mediatization in Russia? What are the main channels and their significance for science communication in the global world?

\section{Methodology}

As is known, science originated in natural philosophical views. Up to the New Time, carrying out logical boundaries between objects and phenomena, different fields of knowledge (philosophy, mathematics, physics, poetics, and rhetoric) were perceived as a single knowledge of the world as a whole.

The search for a universal scientific methodology was also characteristic for others, later methodological schools, such as semiotics.

In the modern scientific environment, there is a constant talk about a "new evolutionary synthesis": Many believe that the development of biology is constrained by the lack of an adequate theoretical basis, a comprehensive new theory that could make the search for new knowledge more meaningful and constructive (Markov 2015, 18-19). 
The famous science popularizer Richard Dawkins extrapolates biological processes to the cultural information dissemination (dichotomy: "gene / meme"), and defined science as the "magic of reality" (Dawkins, 2011). The noted positions, based on the concepts of convergence of knowledge, are conceptually fundamental to the present study.

As specific research methods cultural-historical and comparative historical method were used.

\section{Discussion}

Model of the knowledge in the West is based on the separation of science / art. Max Weber made a distinction between universal and narrowly specialized knowledge in the definitions: "science as a vocation and profession" (Weber, 1946). In such logocentric and metaphysical country, like Russia, these dichotomies are not entirely justified. The very type of national consciousness tends to traditionalism and syncretism. In addition, Russia has not had the historical preconditions for the narrow specialization formation. One of the most significant cultural reasons was not as consistent, as compared with the Western Europe, a Russian classic hierarchy development (Kondakov and Sokolov and Hrenov 2011). However, the humanitarian component was placed in the foundation of the Russian system of science mediatization (Lazarevich 1981). So, in Russia, the understanding of science popularization is wider than in the West.

Other main feature: Russian science has never been separated from the public life. Russian classical universities, as well as the whole system of education, were based on the German model, named "Humboldt model", never aspired to be a "state within a state" (Andreev 2009). In the aspect of interaction: science - society, biography of Dmitry Mendeleev is representative. Recognized scientist, ruler of the minds of young people studying at 1880s, Mendeleev also acted as public person. He was the author of scientific and journalistic book "To the Knowledge of Russia: Treasured Thoughts"; he was also the active member of the various societies. In 1890, he retired from the St. Petersburg Imperial University at the reason that he tried to defend the student's rights. The story was that Mendeleev agreed to transfer to the Minister of education the student's petition demanding university autonomy (which once again was canceled). The Minister refused to accept the petition, and in response Mendeleev did not consider the opportunity to continue serving in the Ministry of Education. He left university, despite the fact that the Council of the university turned to him with a request not to commit this act.

We could give another example. In Russia, even methodological schools, maintained themselves through the journalistic discourse. On the way of magazine controversy, Russian mythological school positioned itself 
at the turn of the $1840 \mathrm{~s}$ - 1850s. Russian formalism school laid the foundation of accurate literary criticism in the 1920s also tended to various forms of publicity. It is also significant that in Russia was formed a unique socio-cultural type, such as "intelligentsia". The basic quality of the Russian "intelligentsia" is realization moral obligation to society. The implementation of this debt occurred to the widespread enlightenment (the organization of schools, educational societies, and so on). At the turn of the nineteenth and twentieth centuries, enlightenment initiatives targeted at various social strata became common. At that time, the main organizers of cultural and enlightenment activities were patrons, having different social status, who established worker's enlightenment societies, people's universities and people's houses. Many Russian intellectuals (professors, pedagogues, lawyers, doctors, etc.) took an active part in the different enlightenment activities, thus realized the moral and ethical concept of "the intelligentsia's duty to the people". A somewhat different approach to enlightenment and popularization of science was established in the Soviet time (more precisely, in the second half of the twentieth century), when outstanding Soviet scientists (not just enlighteners or "intelligentsia") participated in the work of an extensive network of various scientific societies and associations (for instance, the "Knowledge" ('Znanie') society).

Traditionally, Russian science was public-oriented to society. And a special role in this way still belongs to the popular science journalism (Akopov 2002).

Scientific topics have always been presented in the different types of media, and in the context of the different historical periods. In terms of the civil society development, science coverage represented an ideological niche. In some epochs, exactly in the popular science journalism social and political polemics were concentrated (under the typical Russian conditions of the current political discourse reduction); in others (as in Soviet times), this sphere was less loaded with inevitable propaganda. Traditionally, scientific and popular science media were censored much more mildly than socio-political ones. During the Soviet era, the presenter of the famous television program "The Obvious - the Unbelievable" ('Ochevidnoe Neveroyatnoe') Sergey Kapitsa often allowed polemical style of the discussion. This was not typical to the dogmatic Soviet press as a whole. The Soviet press paid much attention to the scientific life, but during the periods of liberalization ("ottepel", "perestrojka"), problems and shortcomings of science life were also discussed. Even in Soviet times, the Academy of Sciences often independently made decisions that contradicted Communist party directives. 
It is usually believed that the constructive model of scientific enlightenment was typical for the Soviet era, but its essential features were formed in the pre-revolutionary time.

In the nineteenth-century Russia, popular science works were published on a regular basis first in encyclopedic and then in the classical large-volume magazines. The idea of the commonwealth of sciences was central to the whole tradition of the national popular science journalism. In the classic Russian $19^{\text {th }}$ century "thick" magazines ("Contemporary", "Fatherland Papers"), departments of politics, science and literature were mixed. The first issue of the most famous Russian popular science magazine was published in 1890. We are talking about "Science and Life", positioned itself as a "literary, artistic, social and popular science magazine". All subject areas were representative in terms of cognition; prerevolutionary "Science and Life" was opened by the mixed department "Science and art". The subsequent rise of the magazine popularity already in Soviet time, was determined by the fact that its audience was formed as Soviet intelligentsia, wanted to learn how things were going in the other areas of knowledge. In the popular science magazine science was presented as knowledge of the whole world. Approach to the understanding scientific knowledge as universal knowledge was typical to the classical Russian popular science magazines.

This trend was manifested in the early twentieth century too, despite the fact that large-volume magazines lost their leading positions. One of the best Russian pre-revolution magazines: “The Russian Wealth') (1876 1918) - was a literary, scientific and social magazine. At that, science was combined with criticism, for instance, in "The Scales", a symbolist scientific and literary and critical monthly magazine, edited by famous poet-symbolist Valery Bryusov. The life-changing era of the early twentieth century featured a scientific and technological breakthrough that affected not only the global landscape, but also the daily life of people.

In the popular science press of the culturally ornate era of the early $20^{\text {th }}$ century, natural sciences could be interpreted as a component of the cultural process (as in the magazine: "The World of Discoveries, a two-week popular illustrated magazine of new discoveries and inventions in all fields of engineering and natural science" (Saint Petersburg, 1912-1913). Accordingly, the enlightenment and entertainment of the audience through travelogues or adventure literature were perceived as an integral part of the voluminous near-scientific picture of the world formation.

The prototypes of the Russian popular science magazines included British illustrated magazines. Novelties of foreign science and literature were brought to the notice of educated modern readers on a regular basis. A symptomatic fact was the emergence of the "Science and Civilization News" 
segment in the popular small-volume illustrated magazine titled "Vsemirnaya Illyustratsiya" ('World Illustrated') (1869 - 1898), which in combination with its supplements had a significant influence on the further popular science magazines development. In the early twentieth century, newspapers started featuring the scientific society chronicler (reporter) position. Mass newspapers began using scientific agenda to form newsbreaks in terms of sensationalism (the circumstances, in which a whale was caught, etc.). Mass periodicals generally gravitate towards the popular science element. For instance, "Top-Secret", one of the first Russian tabloids that was launched during the Gorbachev "perestrojka" (restructuring), still considers itself as a popular science newspaper. This is additional evidence of the Russian general audience latent interest in science, which should be explicated. The Russian audience traditionally interested in acquiring scientific knowledge, which gives ample opportunity for popularizing science, which is insufficiently implemented at present.

From the dynamics of development point of view, popular science press is a unique segment of the Russian press. It has changed little in history. The Soviet model of popular science press was essentially borrowed from the pre-revolutionary times. In this sense the system and typological features of popular science publications late XIX - early XX centuries should be considered classical for the following stages.

After the revolution of 1917 , in many spheres of public life the cultural succession continued to function paradoxically. In the culture area, modernist trends were clearly preserved until about the middle of the 1920s, which was determined by the most powerful culture potential of the century. At the same time, scientific continuity explicitly manifested itself in the Soviet Union during the longer period of time than the cultural or institutional one. The cardinal change of the scientific paradigm occurred in the Soviet period only after the World War II, and science in the USSR in the 1920s - 1930s developed under the direct influence of the breakthrough, advanced science of the turn of the XIX - XX centuries. This kind of specific continuity (which took place, despite the middle level scientific stuff departure, mostly successfully settled in the West), in our opinion, is explained by the following main factors.

First, in the young Soviet state at the beginning was no own scientific policy, and, as in the case of the construction of other state institutions (for example, the censorship body), the model used in the Russian Empire was taken as a basis. Secondly, the international pathos of the Russian revolution at first helped to actualize interest in the Western culture and science. Such, in particular, was a large-scale series "World Literature", created on the initiative of A.M. Gorky. And, finally, thirdly, in accordance with the ideological guidelines of the Soviet state, the level of mental folk 
development has to be brought closer to the scientific experience, since, as we know, Marxism was interpreted as a purely scientific worldview. It should be noted that significant positive results were achieved along this path (one of the first and most important was the successful campaign to eliminate illiteracy).

The designation was accompanied by an active and original development of scientific communication. Throughout the Soviet era, popular science journalism was closely connected with Soviet science and, at the same time, represented, as we mentioned, a certain ideological niche. From the total propaganda it was protected by the entrenched and largely fair idea that prerevolutionary popular science magazines were served as a legal channel for the spread of Marxism. That is why some publishers-educators of the previous era, such as P.P. Soikin, got the opportunity for more or less unhindered activity in the USSR. Throughout the Soviet period, there was a quantitative growth of the popular science press. By the end of the existence of the USSR, at that time the most reading power in the world, every $20^{\text {th }}$ published book belonged to the category of popular science.

Thus, in a short historical period, the revolutionary reorganization of society actualized paradigms change and the "projects of the future". In the long perspective, the successes of many branches of Soviet science (not only cosmonautics, but also, at a certain stage, one of the most authoritative in the world Soviet philological school) were provided both by state support, and by the specific action of the scientific continuity mechanisms. In the USSR, science was respected, partly in the ancient, magical sense (in this sense, the fate of the Nobel Prize winner in physics Peter Kapitsa was indicative).

\section{Results}

As a reference point in the history of the science promotion in Russia, the boundary of the nineteenth and twentieth century stands out. At that time, the model of the popular science journalism was formed. This model was included openness of the knowledge, and the commonwealth of sciences, as well as the audience self-education. This model has been taken by the Soviet popular science press as the basis. The Soviet system of science communication was based on the desire to raise the level of the Soviet folk to the scientific level. That is in many ways determined the USSR power.

\section{Conclusion}

From the modern terminology point of view, the very model of the popular science press, formed before Russian revolution, should be determined as a trans-media, or hybrid media, with an organic combination of the education and entertainment. Probably, such a model can be considered optimal. It is produced by well-coordinated work of the most 
important social institutions of society: education, enlightenment, journalism. Thus, it seems productive to form several types of the science mediatization historical models based on three main factors of influence: 1) the level of development and publicity of the science itself, 2) the general processes taking place in the press, and the degree of its social responsibility, and 3) the activities of other educational institutions of society.

The convergence of science and society requires adapting historical mechanisms to the current situation, and there implementation in practice. Identified trend towards hybridization, and convergence of sciences is fully characteristic for the modern projects in the field of popular science. Now popular science is actively developing not only in traditional, but new media, understood in the broadest sense. And this tendency is global. Popular science located on the cultural and educational portals (such as Russian "Arzamas"), in the format of intellectual battles (such as "Science Slam'), in various educational clusters ("Ohta Lab" in Saint Petersburg). In many ways, these projects continue the central idea, typical to the whole Russian science mediatization tradition, of the different sciences commonwealth. Implicitly following tradition, these projects also in principle retain a dominant setting not so much on promoting science itself, but the development of the audience worldview. And this is the most important feature distinguishing the process of science mediatization in Russia from the specialized Western practice.

\section{Acknowledgment}

The authors gratefully appreciate the support of the Russian Foundation for Basic Research (RFBR). The project No. 16-03-50128.

\section{References:}

1. Akopov, A.I. Some questions of journalism: History, theory, practice. Rostov n/D.: Terra, 2002.

2. Andreev, A.Yu. Russian universities of the $18^{\text {th }}$ - the first half of the $20^{\text {th }}$ centuries in the context of the university history of Europe. Moscow: Sign, 2009.

3. Dawkins, Richard. The Magic of Reality: How We Know What's Really True. New York; London; Toronto; Sydney; New Delhi: Free Press, 2011.

4. Kondakov, I.V., and Sokolov, K.B., and Hrenov, N.A. Civilizational identity in the transitional era: cultural, sociological, and art criticism aspects. Moscow: Progress-Tradition, 2011.

5. Lazarevich, E.A. Popularization of science in Russia. Moscow: Moscow University Publishing, 1981. 
6. Markov, A.V. The birth of complexity. Evolutionary biology today: unexpected discoveries and new questions. Moscow: Corpus, 2015.

7. Weber, Max. "Science as a Vocation". In: Essays in Sociology, by Max Weber, 129-156. New York: Oxford University Press, 1946. 